\begin{tabular}{c|c|c}
\hline \hline Vol. 241: 1-11, 2002 & MARINE ECOLOGY PROGRESS SERIES \\
Mar Ecol Prog Ser & Published October 4 \\
\hline
\end{tabular}

\title{
Large viruses in Ross Sea late autumn pack ice habitats
}

\author{
Marcia M. Gowing ${ }^{1, *}$, Blake E. Riggs ${ }^{1, * *}$, David L. Garrison ${ }^{2,1}$, Angela H. Gibson ${ }^{1, * * *}$, \\ Martin O. Jeffries ${ }^{3}$ \\ ${ }^{1}$ Institute of Marine Sciences, University of California, Santa Cruz, California 95064, USA \\ ${ }^{2}$ Division of Ocean Sciences, National Science Foundation, 4201 Wilson Blvd., Arlington, Virginia 22230, USA \\ ${ }^{3}$ Geophysical Institute, University of Alaska Fairbanks, Fairbanks, Alaska 99775, USA
}

\begin{abstract}
Large (>110 to $424 \mathrm{~nm}$ capsid diameter) extracellular viruses occurred in Ross Sea first year ice samples at 33 stations from 66 to $78^{\circ} \mathrm{S}$ during the period from 9 May to 11 June 1998. As the viruses were of a size and morphology likely to infect algae and protozoans, infected eukaryotes were present in ice habitats as winter approached. Abundance ranged from below detection limits to $2.5 \times$ $10^{6} \mathrm{ml}^{-1}$ brine (the liquid component of sea ice). It was positively correlated with chlorophyll a (chl a) and phaeophytin and did not differ among vertical location in cores or with ice type. Transmission electron microscopy (TEM) of thin sections of more than 9000 diatoms revealed no viruses; it is therefore unlikely that diatoms were the source of the viruses in the samples. Despite examination of over 2000 other algal cells and heterotrophs, we only observed 5 infected unidentified heterotrophs. They were from bottom communities at 2 stations with chl a ranging from 16 to $73 \mu^{-1}$ and where several taxa were present as $10^{4}$ to $10^{5}$ cells $\mathrm{ml}^{-1}$ melted sample. Although viruses of all sizes occurred in fecal pellets from ice habitats and in food vacuoles of phaeodarian radiolarians from water directly below the ice, we did not observe viruses in food vacuoles of ice community microheterotrophs. Viruses were therefore not a major food source in late autumn. Abundance of total (all sizes) viruses (10 to $10^{9} \mathrm{ml}^{-1}$ brine, equivalent to $10^{6}$ to $10^{8} \mathrm{ml}^{-1}$ melted core sample) in a subset of samples was comparable to, or higher than, abundance from other polar locations, suggesting the importance of the total viral community in ice community dynamics.
\end{abstract}

KEY WORDS: Viruses $\cdot$ Pack ice $\cdot$ Ross Sea Resale or republication not permitted without written consent of the publisher

\section{INTRODUCTION}

Viruses influence many aspects of carbon flow in marine ecosystems (Fuhrman 1999, Suttle 2000, Wommack \& Colwell 2000). For example, algal viruses have been implicated in phytoplankton bloom dynamics in lower latitude waters (reviewed by Zingone 1995). There are no similar data from polar waters where sea ice communities of eukaryotic algae and protozoans

\footnotetext{
*E-mail: gowing@cats.ucsc.edu

Present addresses:

**Biology Department, University of California, Santa Cruz, California 95064, USA

*** Ocean Sciences Department, University of California, Santa Cruz, California 95064, USA
}

sometimes reach high densities in microhabitats that are isolated for parts of the year (Horner 1985, Garrison 1991, Palmisano \& Garrison 1993). Viruses have been reported from Arctic sea ice (Maranger et al. 1994a), Antarctic marine waters (reviewed by Karl et al. 1996, Marchant et al. 2000), and Antarctic lakes (Kepner et al. 1997, 1998, Wilson et al. 2000). Although the majority of the viruses in these studies were thought to be bacteriophages, the authors noted that some could have infected algae or protozoans, especially in the lake samples.

Most ice communities reach peak abundance in spring and summer, and viruses would be most likely to affect population dynamics at those times. Autumn sea ice algal blooms, usually with smaller accumulations of biomass, have been reported from near Syowa 
Station in the Indian Ocean sector (Hoshiai 1985) and from areas in the Weddell Sea (Gradinger et al. 1993, Fritsen et al. 1994; also see Palmisano \& Garrison 1993 for a review). Viral infection might be enhanced in the autumn when solar UV radiation decreases (e.g. Wilhelm et al. 1998). In addition to affecting food webs by lysing cells, viruses of both eukaryotes and prokaryotes are also potential prey for microheterotrophs (e.g. González \& Suttle 1993). Protozooplankton from natural Antarctic populations have been observed with ingested virus-like particles in their food vacuoles (Gowing 1993).

On a late autumn cruise of the RV 'Nathaniel B. Palmer' we sampled Ross Sea pack ice microhabitats ranging from the ice edge to the continent. Our objectives were: (1) to determine the abundance of large ( $\geq 110 \mathrm{~nm}$ capsid diameter) extracellular viruses likely to infect algae and protozoans in ice surface, interior and bottom habitats and in ice of various physical structures; (2) to document infections of algae and protozoans; and (3) to examine the extent of ingestion of

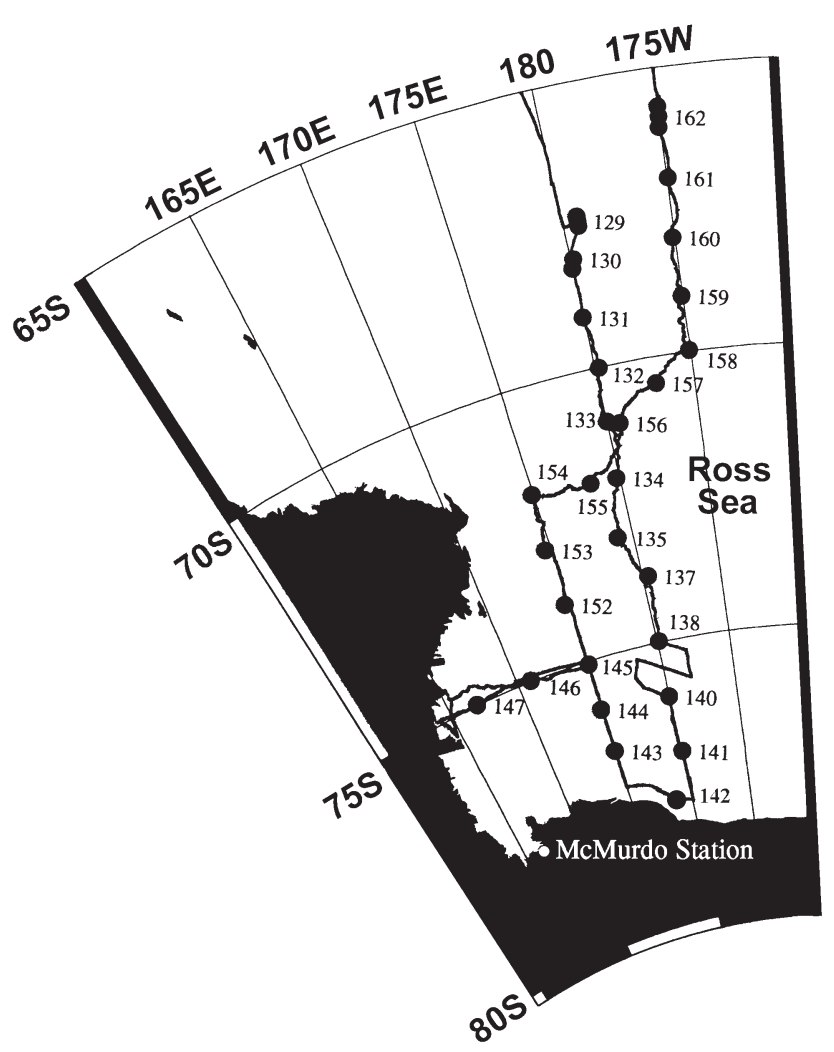

Fig. 1. Cruise track and station locations. Station number corresponds to day of the year; Stn 129 was sampled 9 May 1998 and Stn 162 was sampled 11 June 1998. Stn 142 was land-fast ice; other stations were pack ice. Two sites were sampled on Day 129, 3 on Day 130, and 3 on Day 162. This image was modified from the original cruise track provided by T. Schunck and C. Masters viruses by sea ice protozoans and by protozoans in water directly below the ice. We also report the total (all sizes) extracellular viral abundance from a few ice cores. To our knowledge this is the first study focusing on putative eukaryotic viruses.

\section{MATERIALS AND METHODS}

Sample collection. On the Ross Sea cruise NBP98-3 of the RV 'Nathaniel B. Palmer' from 9 May until 11 June 1998 we sampled sea ice at 33 stations and water and plankton from directly below the ice at some stations (Fig. 1). Sampling occurred at approximately every degree of latitude between 66 and $78^{\circ} \mathrm{S}$, and 1 station was generally sampled each day. Floes were selected as representative of the ice cover in the area. On small floes requiring access via a personnel basket lowered over the side of the ship, 1 site was sampled. On floes large enough for the ship to park in, a $150 \mathrm{~m}$ transect was laid out to be as representative as possible of the floe's surface topographic variability. Three sites along the transect, representative of unridged ice topographic variability, were selected for ice coring for ice physics studies (e.g. Jeffries et al. 2001). If the ice physics core was visibly colored at a site, a virus core was taken there; otherwise a virus core was taken from the site closest to the ship. Ice cores of $7.5 \mathrm{~cm}$ diameter were taken with a motorized corer and immediately measured and split into either 10 or $20 \mathrm{~cm}$ sections using a saw. Where natural breaks or bands of color occurred in a core, section lengths were adjusted to avoid splitting those features. Each section was usually split longitudinally to provide aliquots for 2 different melting regimes (described below). Core sections were placed in plastic bags in an insulated box to minimize temperature changes during transport to the ship. Replicate cores for ice structure analysis, temperature and bulk salinity measurements (methods of Jeffries \& Adolphs 1997), and ice community analysis (chl a and microscopy: Garrison et al. 1999) were taken within approximately $50 \mathrm{~cm}$ of the virus cores. We assumed that features of the replicate cores at each station were similar; we did not test this. Water samples (2 1) were collected from the core hole using a diaphragm pump with tubing extending about $50 \mathrm{~cm}$ below the bottom of the hole. Plankton tows were taken through the core hole to a depth of $5 \mathrm{~m}$ with a $10 \mu \mathrm{m}$ mesh net with a $6 \mathrm{~cm}$ mouth. Brine samples were collected from brine holes in the vicinity of the core samples. Holes were drilled to within about $10 \mathrm{~cm}$ of the bottom of the ice with an ice auger, covered with pieces of plywood, and allowed to accumulate brine for a few hours. Brine salinity was measured in the field with a 
refractometer; samples with abnormally low salinities (indicating that seawater had flooded the holes) or from holes that appeared flooded were discarded.

Sample processing and examination. Samples were processed for extracellular virus counts and for bulk community analysis of infected cells and ingested viruses in cell sections. A 'fast melt regime' was used to prevent grazing of heterotrophs on viruses, and a 'slow melt regime' was used to minimize loss of delicate cells from osmotic shock (Garrison \& Buck 1986). Onboard ship, the 'fast melt regime' core sections (for virus counts and bulk community preparations) were placed in a mixture of 82 or $168 \mathrm{ml}$ of $0.02 \mu \mathrm{m}$ filtered seawater with 18 or $32 \mathrm{ml} 5 \%$ borate-buffered $20 \%$ paraformaldehyde, respectively (giving a final fixative concentration of $\sim 1 \%$ ), and allowed to melt overnight at room temperature. When melting was complete, the total volume was measured to determine the dilution, and aliquots for virus counts were removed to sterile centrifuge tubes and refrigerated. 'Slow melt regime' core sections (for bulk community preparations) were placed in $1 \mathrm{l}$ of $0.2 \mu \mathrm{m}$ filtered seawater (Garrison \& Buck 1986) and allowed to melt in the dark at approximately $2^{\circ} \mathrm{C}$. At the few stations for which core sections were not split longitudinally for the different melting regimes, sections were melted under the slow regime using $2 \mathrm{l}$ of $0.2 \mu \mathrm{m}$ filtered seawater. After complete melting (usually 2 d) these samples were measured to determine the dilution and preserved with borate-buffered paraformaldehyde (1\% final concentration).

Brine, plankton and water samples were preserved immediately upon return to the ship; $0.02 \mu \mathrm{m}$ filtered fixative was used for aliquots for virus counts and $0.2 \mu \mathrm{m}$ filtered fixative was used for aliquots for bulk community preparations and for plankton tows.

Samples for counts of extracellular larger viruses using TEM were shipped to the home laboratory under refrigeration via air. Viruses in aliquots of 10 or $20 \mathrm{ml}$ (2 sequential $10 \mathrm{ml}$ aliquots) were centrifuged $\left(2 \mathrm{~h}\right.$ at $\left.288000 \times g, 25^{\circ} \mathrm{C}\right)$ in a Beckman L7-65 ultracentrifuge with a SW-41Ti rotor and stained with $0.5 \%$ uranyl acetate (the general protocol of Steward et al. 1996). We used 400 mesh carbon/formvarcoated copper grids (Electron Microscopy Sciences) that had either been coated with poly-L-lysine (Mazia et al. 1975) or had been made hydrophilic by glow discharge (Cochlan et al. 1993). Two grids were placed on a polycarbonate support for centrifugation (Wells \& Goldberg 1992). Ten to 20 entire grid squares were viewed at $17000 \times$, and viruses of icosahedral, spherical, or 'lumpy' shape with a capsid diameter $\geq 110$ nanometers $(\mathrm{nm})$ were counted and measured using a stereoscope eyepiece reticle with concentric circles. The 'lumpy' category included par- ticles that were intermediate between icosahedral and spherical. A commercial calibration grid was photographed at all magnifications used during each TEM session and was used to determine the true magnification (on our microscopes the true magnification typically differed from the displayed magnification by $\pm 15 \%$ ). An average grid square area was determined for each grid by measuring dimensions of grid square openings with a compound microscope; abundances of the viruses were calculated using the formula of Suttle (1993). The numbers of viruses counted per sample ranged from 0 to 357 and were generally 50 or fewer.

Ultrastructural morphology does not allow all viruses of eukaryotic cells to be distinguished from all bacteriophages. We have chosen the conservative criteria of an icosahedral, lumpy or spherical shape, dense staining, and capsid diameter $\geq 110 \mathrm{~nm}$ as indicative of viruses of eukaryotes. The size criterion was chosen because: (1) the average capsid size for viruses infecting eukaryotic algae is $152 \mathrm{~nm}$ (SD $108 \mathrm{~nm}, \mathrm{n}=46)$, although $28 \%$ are smaller than $60 \mathrm{~nm}$ (van Etten et al. 1991, cited in Cochlan et al. 1993; also see Lawrence et al. 2001); (2) the 4 divisions on our reticle used as a size cutoff gave a minimum size of $110 \mathrm{~nm}$ when the microscope magnifications were calibrated $;$ and (3) a study of sizes of marine bacteriophages showed that they ranged from 30 to $<110 \mathrm{~nm}$ (Weinbauer \& Peduzzi 1994).

Samples for bulk community preparations $(\sim 500 \mathrm{ml}$ to $\sim 21$, depending on the ice characteristics and melting regime) were reduced to a volume of about $15 \mathrm{ml}$ at sea by low vacuum filtration over $47 \mathrm{~mm}$ diameter, $2.0 \mu \mathrm{m}$ pore size polycarbonate filters. Generally, the slow melt samples were embedded at sea and the fast melt, water and brine samples were embedded at the home laboratory after being shipped under refrigeration by air. Organisms were pelleted by centrifugation $(16500 \times g)$ in molten agar $(2 \%$ in $80 \%$ seawater $)$ that cooled during centrifugation. The pellet was cut into $\sim 1 \mathrm{~mm}^{3}$ blocks that were returned to the paraformaldehyde fixative, rinsed in $0.1 \mathrm{M}$ sodium cacodylate in $80 \%$ seawater, post-fixed in $1 \%$ osmium tetroxide in buffer, rinsed in cacodylate buffer, gradually brought to deionized water, dehydrated in a graded acetone series, infiltrated and then embedded in Spurr's resin (Spurr 1969). Sections of $1 \mu \mathrm{m}$ thickness were cut from several blocks for each sample, stained with $1 \%$ toluidine blue in $1 \%$ sodium borate, and examined at $400 \times$ with a light microscope. Blocks with a diversity of cells and those with many similar cells were then thin sectioned. Thin sections were cut with a diamond knife, collected on formvar-coated grids, stained with uranyl acetate and lead citrate (Reynolds 1963), carboncoated, and examined at $80 \mathrm{kV}$ with a JEOL 100B or a 
JEOL 1200EX transmission electron microscope. Sections were viewed at 12000 to $17000 \times$ and examined for cells with visible viral infections and for heterotrophs with viruses in their food vacuoles. All cells observed in 1 section were identified to a broad taxonomic group and counted. Additional sections were examined but not counted (to avoid counting the same cells more than once).

Phaeodarian radiolarians (Challengeron bicorne, Protocystis tridens and $P$. harstoni) from plankton tows were used as particle samplers of the water directly below the ice. These protozoans are trophic generalists (e.g. Gowing 1989, 1993) and have the unique habit of retaining their waste vacuoles in a copious mass called a phaeodium (Cachon \& Cachon 1985). One to 3 individual phaeodarians from Stns 137, 138, 143, 152 to 155, and 158 to 161 were enrobed in agar and embedded for TEM as described above. Sections were viewed at $30000 \times$, and food and waste vacuoles were examined for viruses.

Samples for total (all sizes) extracellular virus counts on filters using light microscopy were prepared at sea using the protocol for SYBR Green I (Noble \& Fuhrman 1998) or Yo-Pro-1 (Xenopoulos \& Bird 1997). Replicate filters with 0.2 to $2 \mathrm{ml}$ were prepared for each sample, and solution blanks were prepared each time batches of samples were processed. Filters were mounted in ProLong $^{\mathrm{TM}}$ Antifade medium (Molecular Probes) on slides, frozen at $-80^{\circ} \mathrm{C}$, shipped surrounded by dry ice to the home laboratory via air, and again stored at $-80^{\circ} \mathrm{C}$. Thawed slides were viewed at $1000 \times$ with an Olympus BX-60 epifluorescence microscope equipped with an Acridine Orange filter set. A minimum of 200 virus-like particles in 20 fields of view was counted for each sample.

Terminology and data presentation. We are using the term virus for convenience. Since the particles have not been shown to cause infection, they are more correctly referred to as virus-like particles. Abundance of total viruses and viruses $\geq 110 \mathrm{~nm}$ from core sections are reported in $\mathrm{ml}^{-1}$ brine because we assume that these particles are suspended in brine inclusions, rather than entrapped in the ice matrix. Brine volume in the ice was calculated from the temperature and bulk salinity of the adjacent core using the formula of Cox \& Weeks (1983). For total viruses, abundances $\mathrm{ml}^{-1}$ melted sample are also given to allow a comparison with the Arctic ice study of Maranger et al. (1994a). Brine volumes in the samples ranged from 4 to $9 \%$ of surface core sections, from 3 to $17 \%$ of interior core sections, and from 6 to $21 \%$ of bottom core sections. Thus abundances $\mathrm{ml}^{-1}$ brine were always higher than abundances $\mathrm{ml}^{-1}$ melted sample, and there is no single conversion factor. Similarly, there is no single detection limit because brine volumes varied among samples.

\section{RESULTS}

The abundance of extracellular viruses $\geq 110 \mathrm{~nm}$ in capsid diameter in core sections ranged from below detection limits to $5.6 \times 10^{5} \mathrm{ml}^{-1}$ brine in surface habitats, below detection limits to $2.5 \times 10^{6} \mathrm{ml}^{-1}$ brine in interior habitats, and below detection limits to $1.2 \times 10^{6}$ $\mathrm{ml}^{-1}$ brine in bottom habitats (Table 1, Fig. 2). Where large viruses were detected, abundances ranged over 3 orders of magnitude and showed no pattern related to latitude (Fig. 2). Abundances of viruses did not differ significantly as a function of ice habitat (e.g. surface, interior, or bottom habitats) or ice structural composition (e.g. frazil, congelation, or mixed structure) (Kruskall-Wallis test, p > 0.05; tests among habitats and structural types calculated separately for all core samples). Abundances of large viruses in core sections were positively correlated with chl a (Spearmann rank correlation coefficient $\mathrm{R}_{\mathrm{S}}=0.53, \mathrm{p}<0.001, \mathrm{n}=87$ sample pairs) and with phaeophytin $\left(\mathrm{R}_{\mathrm{S}}=0.44, \mathrm{p}<0.001\right.$, $\mathrm{n}=87$ sample pairs), which would be expected if algae are among the hosts. Abundances in brine samples

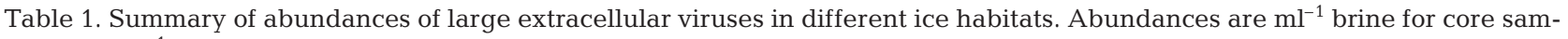
ples and $\mathrm{ml}^{-1}$ for brine hole samples. b.d.l. = below detection limits (none counted in 20 TEM grid squares; see methods section for explanation). -: not applicable. Confidence limits were calculated as described by Lund et al. (1958). Ice cores ranged in thickness from 29 to $126 \mathrm{~cm}$. Brine hole depths ranged from 19 to $80 \mathrm{~cm}$

\begin{tabular}{|c|c|c|c|c|c|c|c|}
\hline $\begin{array}{l}\text { Sample } \\
\text { type }\end{array}$ & Habitat & $\begin{array}{l}\text { Total no. } \\
\text { of samples }\end{array}$ & $\begin{array}{c}\text { No. of } \\
\text { b.d.l. samples }\end{array}$ & $\begin{array}{l}\text { Minimum } \\
\text { abundance }\end{array}$ & $\begin{array}{l}95 \% \text { confidence } \\
\text { limits for minimum }\end{array}$ & $\begin{array}{l}\text { Maximum } \\
\text { abundance }\end{array}$ & $\begin{array}{l}95 \% \text { confidence } \\
\text { limits for maximum }\end{array}$ \\
\hline \multicolumn{8}{|l|}{ Cores } \\
\hline & Surface & 26 & 12 & b.d.l. & - & $5.6 \times 10^{5}$ & $4.4 \times 10^{5}, 7.3 \times 10^{5}$ \\
\hline & Interior & 50 & 11 & b.d.l. & - & $2.5 \times 10^{6}$ & $2.0 \times 10^{6}, 3.2 \times 10^{6}$ \\
\hline & Bottom & 27 & 11 & b.d.l. & - & $1.2 \times 10^{6}$ & $1.0 \times 10^{6}, 1.4 \times 10^{6}$ \\
\hline Brine holes & & 19 & 0 & $1.4 \times 10^{3}$ & $4.6 \times 10^{2}, 4.6 \times 10^{3}$ & $3.2 \times 10^{5}$ & $2.9 \times 10^{5}, 3.5 \times 10^{5}$ \\
\hline
\end{tabular}


from brine holes (a mixture of viruses from surface, interior and bottom habitats) ranged from $1.4 \times 10^{3} \mathrm{ml}^{-1}$ to $3.2 \times 10^{5} \mathrm{ml}^{-1}$ (Table 1 ).

A total of 2758 viruses $\geq 110 \mathrm{~nm}$ in capsid diameter of icosahedral (Fig. 3a-f), lumpy, and spherical morphologies were observed in the whole mount centrifuge preparations. Twenty of the icosahedral viruses had tails (e.g. Fig. 3c-f). Capsid diameters ranged up to $424 \mathrm{~nm}$; the 2 most abundant size classes were 144 to $160 \mathrm{~nm}$ and 178 to $194 \mathrm{~nm}$ (Fig. 4). Large viruses also occurred in association with detrital material in the bulk community preparations examined in thin sections. These included intact viruses (e.g. Fig. 5d-f) and empty capsids (e.g. Fig. 5g).

We examined ultrathin sections of bulk community preparations of 19 brine samples, 102 core sections and 2 water samples that contained a total of more than 1054 dinoflagellates (including autotrophic and heterotrophic forms), 804 other heterotrophs, 9888 diatoms and 604 other algal cells (Table 2). Heterotrophic cells

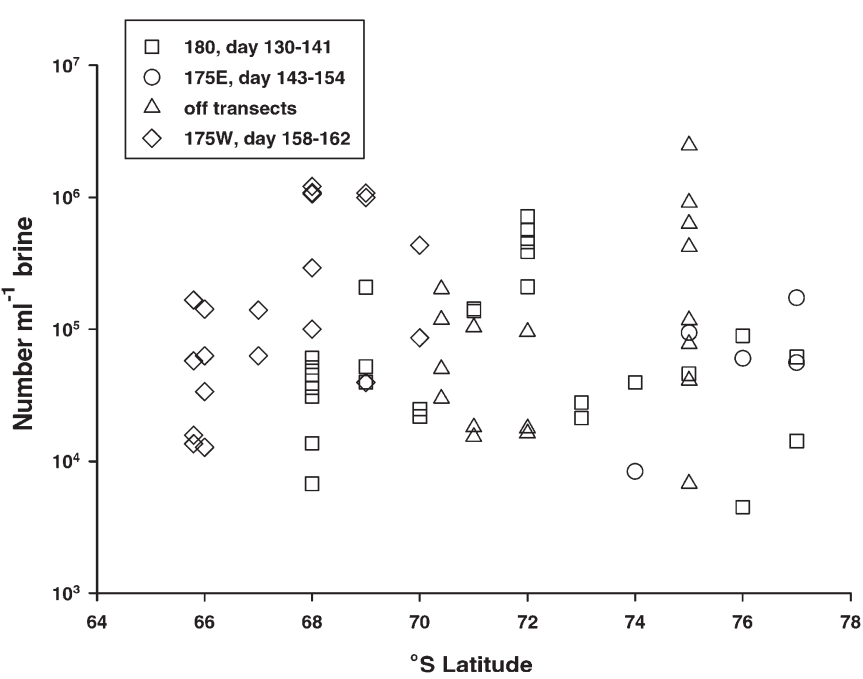

Fig. 2. Abundance of viruses ( $\geq 110 \mathrm{~nm}$ capsid diameter) $\mathrm{ml}^{-1}$ brine in all core sections (surface, interior and bottom habitats) where large viruses were detected

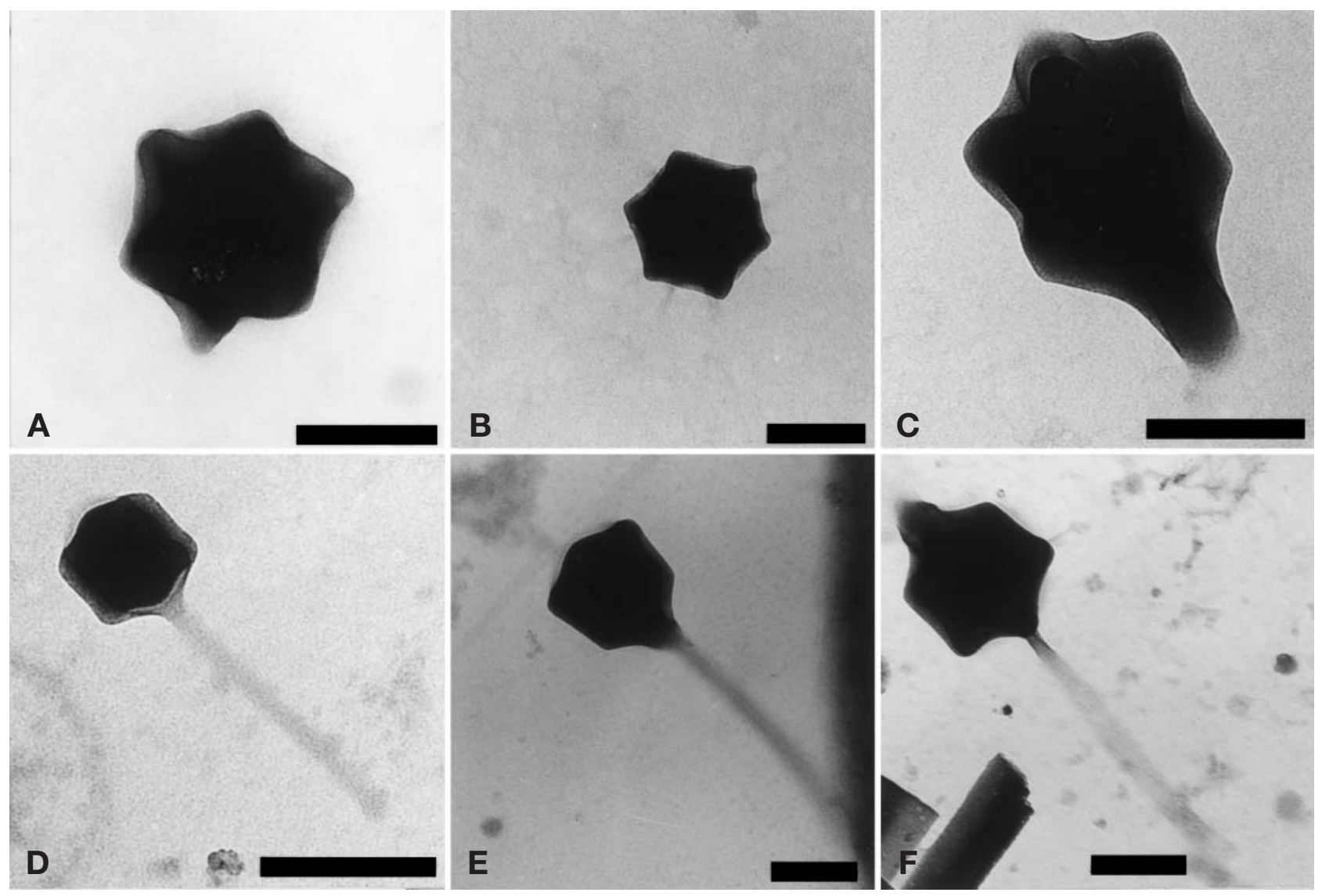

Fig. 3. Whole mounts of larger viruses of icosahedral capsid morphology. (A) Stn 159, bottom $20 \mathrm{~cm}$ in an $84 \mathrm{~cm}$ core. (B) Stn 133 , interior habitat in a $63.5 \mathrm{~cm}$ core. (C) Stn 155, brine from brine hole. (D) Stn 156, brine from brine hole. (E) Stn 159, bottom core section. (F) Stn 160, bottom $10 \mathrm{~cm}$ from a $61.5 \mathrm{~cm}$ core. All scale bars $=200 \mathrm{~nm}$ 


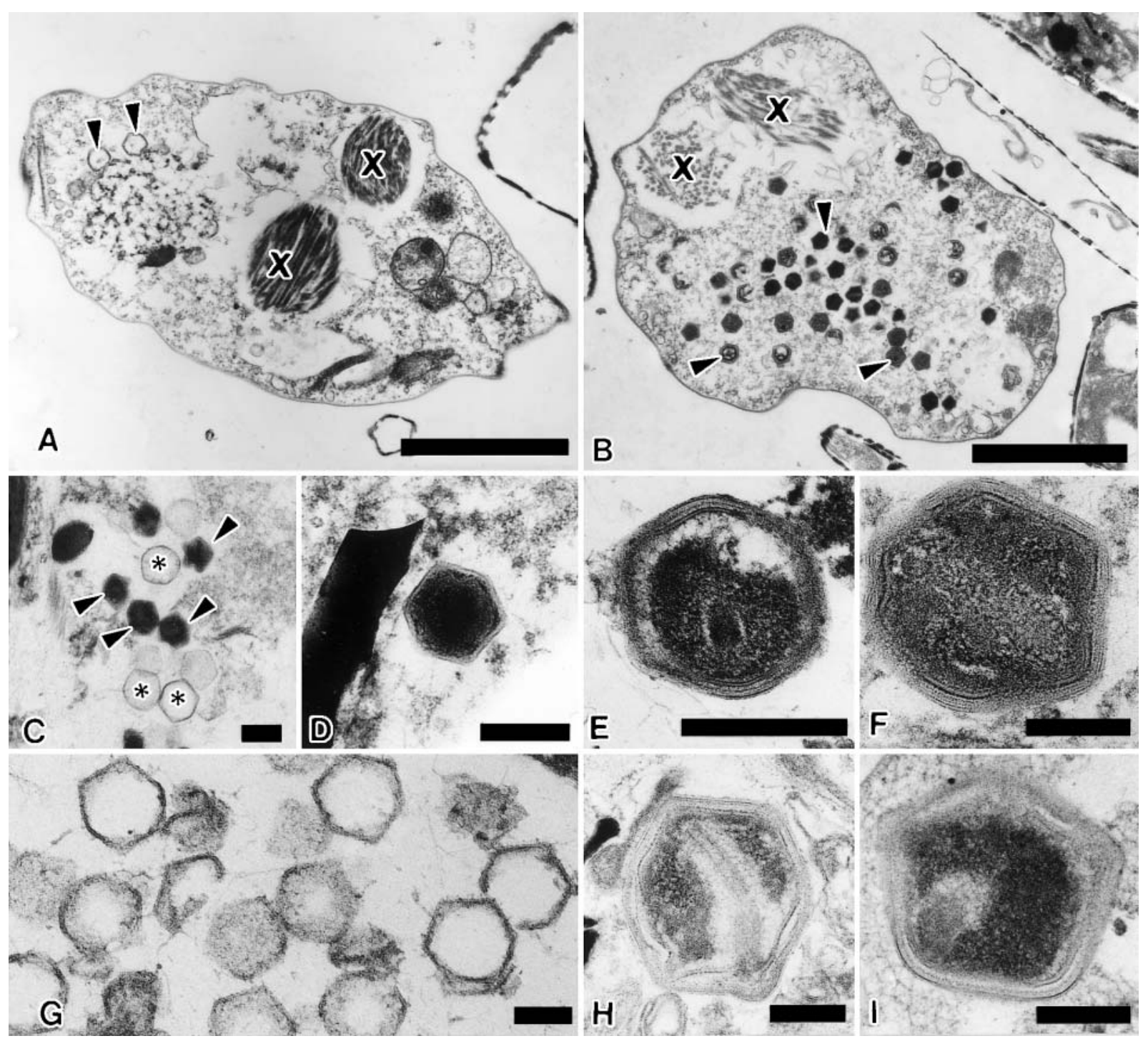

Fig. 5. Thin sections of viruses $\geq 110 \mathrm{~nm}$ capsid diameter. Arrows: viruses. X: food vacuoles containing trichocysts. (A) Section through an infected microheterotroph from the bottom core section at Stn 160. Scale bar $=2 \mu \mathrm{m}$. (B) Section through an infected microheterotroph from the bottom core section at Stn 159. Scale bar $=2 \mu \mathrm{m}(\mathrm{C})$ Viruses and empty capsids (asterisks) from a fecal pellet from an interior habitat at Stn 134. Scale bar $=200 \mathrm{~nm}$. (D) Virus in detrital material from the bottom core section at Stn 129-3. Scale bar $=200 \mathrm{~nm}$. (E) Virus in detrital material from a brine hole sample at Stn 159. Scale bar $=200 \mathrm{~nm}$. (F) Virus in detrital material from the bottom core section at Stn 140. Scale bar $=200 \mathrm{~nm}$. (G) Empty capsids in detrital material from a brine hole sample at Stn 159. Scale bar $=200 \mathrm{~nm}$. (H) Virus from a food vacuole of a phaeodarian radiolarian directly below the ice at Stn 158. Scale bar $=200 \mathrm{~nm}$. (I) Virus from a food vacuole of a phaeodarian radiolarian from directly below the ice at Stn 138. Scale bar $=200 \mathrm{~nm}$

included ciliates, heliozoans, Cryothecomonas spp., Telonema spp., choanoflagellates, aplastidic cryptophytes and other flagellates. Autotrophic cells included non-motile Phaeocystis-like cells, Parmales cells, chrysophyte cysts, motile and non-motile Pyramimonas cells, and other flagellated and non-flagellated cells. We observed only 5 infected cells. These were roughly similar heterotrophs with no specific diagnostic features (e.g. Fig. 5a,b). Two occurred in the bottom $20 \mathrm{~cm}$ of the core from Stn 159, and 3 occurred in the bottom
$20 \mathrm{~cm}$ of the core from Stn 160. Their viruses were icosahedral, 181 to $397 \mathrm{~nm}$ in capsid diameter and were in the cytoplasm. No sections contained a nucleus, but the entire organisms were not serially sectioned.

We observed intact large viruses in fecal pellets from ice cores at 3 stations (e.g. Fig. 5c); capsid diameters ranged from 128 to $513 \mathrm{~nm}$. In fecal pellets at 8 stations we observed empty capsids ranging from 186 to $560 \mathrm{~nm}$ in diameter. Smaller viruses (capsid diameters of 50 to $88 \mathrm{~nm}$ ) were observed in fecal pellets from ice 
Table 2. Summary of cells counted in TEM sections. For each station cell counts from core sections and brine hole samples have been totaled. Dinoflagellates include autotrophic and heterotrophic forms. P: present in low abundance and not counted. Diatom counts are shown as ' $>$ ' when counts were stopped before all cells in a TEM section had been counted. Some other cell counts are shown as '>' when additional cells were present but not counted

\begin{tabular}{|c|c|c|c|c|}
\hline Stn & Diatoms & $\begin{array}{l}\text { Dino- } \\
\text { flagellates }\end{array}$ & $\begin{array}{l}\text { Other algal } \\
\text { cells }\end{array}$ & $\begin{array}{c}\text { Other } \\
\text { heterotrophs }\end{array}$ \\
\hline 129 & $>214$ & 10 & 21 & 10 \\
\hline $130-1$ & $>877$ & 9 & 6 & 10 \\
\hline $130-2$ & $>579$ & 10 & 1 & 8 \\
\hline 131 & $>316$ & 42 & 31 & 17 \\
\hline 132 & $>487$ & 23 & 33 & 30 \\
\hline 133 & $>192$ & 31 & 14 & 23 \\
\hline 134 & $>790$ & 27 & 17 & 27 \\
\hline 135 & $>37$ & 19 & 3 & 8 \\
\hline 137 & 16 & 32 & 4 & 7 \\
\hline 138 & $>15$ & 11 & 3 & 5 \\
\hline 140 & $>19$ & 4 & 2 & 8 \\
\hline 142 & 27 & 31 & 11 & 23 \\
\hline 144 & $\mathrm{P}$ & 5 & 4 & 1 \\
\hline 145 & $\mathrm{P}$ & 10 & 0 & 0 \\
\hline 146 & $>406$ & 11 & 3 & 19 \\
\hline 152 & $\mathrm{P}$ & 8 & 1 & 4 \\
\hline 153 & $\mathrm{P}$ & 23 & 1 & 2 \\
\hline 154 & $>19$ & 64 & 12 & 21 \\
\hline 155 & $>19$ & 23 & 1 & 9 \\
\hline 156 & $>534$ & $>23$ & $>6$ & $>28$ \\
\hline 157 & $>600$ & $>9$ & 45 & $>25$ \\
\hline 158 & $>267$ & 9 & $>74$ & 80 \\
\hline 159 & $>1503$ & 266 & $>158$ & 194 \\
\hline 160 & $>1562$ & 223 & 133 & 185 \\
\hline 161 & $>165$ & 30 & 6 & 11 \\
\hline $162-1$ & $>668$ & 43 & 10 & 14 \\
\hline $162-2$ & $>484$ & 43 & 2 & 30 \\
\hline $162-3$ & $>92$ & 15 & 2 & 5 \\
\hline
\end{tabular}

cores at 6 stations. We observed intact larger viruses (capsid diameter range 152 to $607 \mathrm{~nm}$ ) in 1 phaeodarian radiolarian each from plankton tows at 3 stations (e.g. Fig. 5h,i). Empty capsids (diameter range 177 to $593 \mathrm{~nm}$ ) were observed in 1 phaeodarian each from 4 stations.

Total (all sizes) extracellular viruses in core sections ranged from $1.0 \times 10^{8}$ to $1.5 \times 10^{9} \mathrm{ml}^{-1}$ brine (Table 3 ). The data set is small because problems with filter preparation rendered many filters uncountable; we show only data for samples for which at least 2 replicate filters were counted. At 2 stations entire cores were examined, and abundance did not differ significantly with position in the core. For the 8 core sections for which larger viruses were detectable

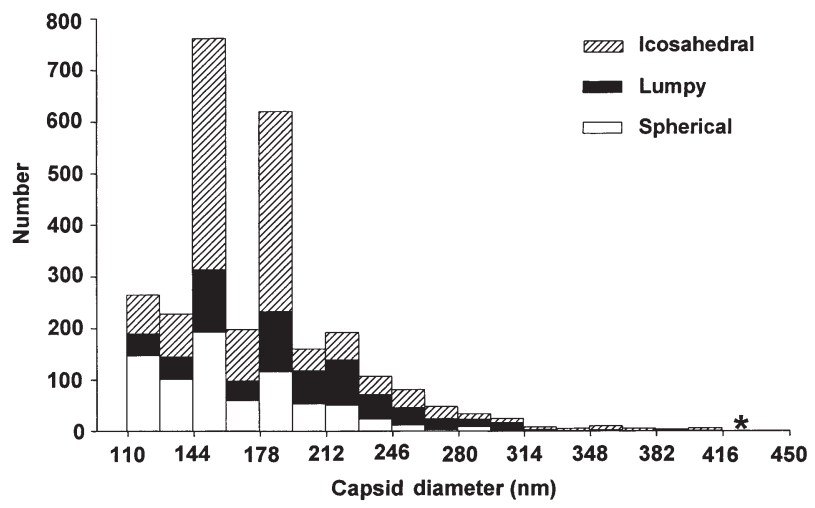

Fig. 4. Size-frequency histogram of viral capsid diameters. Diameters were the maximum diameter. Values are plotted at the mid-point of the size class. Size classes were 110-126, $127-143,144-160 \mathrm{~nm}$, etc. The largest specimen (424 nm capsid diameter) was a single icosahedral one denoted by the asterisk because a frequency of 1 does not show on the plot. Total $\mathrm{n}=2758$

on TEM grids and for which total counts were made on filters, the larger viruses ranged from 0.002 to $1 \%$ of the total viruses.

\section{DISCUSSION}

To provide an overview of the late autumn environment, a synopsis of conditions in the study area follows; detailed analyses of ice structure are reported in Jeffries et al. (2001), and abundance and biomass of organisms of ice communities will be reported elsewhere (Garrison et al. unpubl., Gibson et al. unpubl.). The total ice concentration exceeded $90 \%$ throughout much of the pack ice except for the marginal ice zone immediately adjacent to the open ocean where the

Table 3. Total (all sizes) viral abundances in ice cores. Ranges are the means of counts of 2 filters for all samples except for 1 bottom sample for which 3 filters were counted. Abundance per ml melted sample is included for comparison with the previous literature

\begin{tabular}{|c|c|c|c|c|}
\hline Habitat & $\begin{array}{c}\text { No. } \\
\text { samples }\end{array}$ & Stns & $\begin{array}{l}\text { Range } \times 10^{7} \\
\left(\mathrm{ml}^{-1} \text { brine }\right)\end{array}$ & $\begin{array}{c}\text { Range } \times 10^{7} \\
\left(\mathrm{ml}^{-1} \text { melted sample }\right) \\
\pm \mathrm{SE} \times 10^{7}\end{array}$ \\
\hline Surface & 4 & $\begin{array}{l}135,137 \\
140,153\end{array}$ & $37-150$ & $2.1 \pm 0.01$ to $10 \pm 0.16$ \\
\hline Interior & 10 & $\begin{array}{c}130-1,132 \\
134,135 \\
137,147\end{array}$ & $10-120$ & $1.0 \pm 0.04$ to $7.8 \pm 0.77$ \\
\hline Bottom & 3 & $\begin{array}{c}135,137 \\
147\end{array}$ & $11-30$ & $1.5 \pm 0.41$ to $3.4 \pm 0.001$ \\
\hline
\end{tabular}


concentration was 70 to $80 \%$ at the beginning and end of the cruise (Morris et al. unpubl.). The pack ice was primarily composed of first-year ice from 0.3 to $0.7 \mathrm{~m}$ thick (Morris et al. unpubl.). Snow cover ranged from 0 to $36 \mathrm{~cm}$. Frazil ice predominated north of $70^{\circ} \mathrm{S}$, and congelation ice predominated south of $70^{\circ} \mathrm{S}$ (Jeffries et al. 2001). Chl a concentrations were generally higher north of $70^{\circ} \mathrm{S}$, reaching a maximum of $>20 \mathrm{mg} \mathrm{m}^{-2}$ (Garrison et al. 1999). Air temperatures ranged from 0.5 to $-33.0^{\circ} \mathrm{C}$ and generally decreased with increasing latitude. Solar radiation decreased with latitude and with date, ranging from about $6 \mathrm{~h}$ at $68^{\circ} \mathrm{S}$ on May 1 to $0 \mathrm{~h}$ of light at $76^{\circ} \mathrm{S}$ on June 1 (Garrison et al. 1999).

Abundance (from below detection limits up to $2.49 \times$ $10^{6} \mathrm{ml}^{-1}$ brine, equivalent to $8.2 \times 10^{4} \mathrm{ml}^{-1}$ melted sample) of the large viruses in autumn sea ice is generally comparable to the few data for this size class from other polar locations sampled in different seasons. Large viruses (100 to $120 \mathrm{~nm}$ capsid diameter) in Arctic sea ice spring bloom samples peaked at about $7.5 \times$ $10^{6} \mathrm{ml}^{-1}$ melted sample, equivalent to $10 \%$ of the total viruses on that date, and were otherwise $<1 \%$ of the total viruses (Maranger et al. 1994a). Kepner et al. (1998) reported a November abundance of $6.7 \times$ $10^{3} \mathrm{ml}^{-1}$ at $8 \mathrm{~m}$ in 1 Antarctic lake for viruses with capsids $>100 \mathrm{~nm}$ in diameter; this size class was roughly $1 \%$ of the total viruses in 2 Antarctic lakes. Wilson et al. (2000) remarked that viruses 100 to $180 \mathrm{~nm}$ were common in their Signy Island February lake samples and that a few tailed viruses with $330 \times 370 \mathrm{~nm}$ capsids were observed in 1 lake.

Various types of communities occur at different vertical positions within sea ice (reviewed by Palmisano \& Garrison 1993), and physical processes occurring during sea ice formation affect sea ice communities (reviewed by Garrison 1991, Ackley \& Sullivan 1994). These processes could also directly or indirectly affect viral abundance. Frazil ice forms under turbulent conditions, and algal cells can be harvested by the rising ice crystals or incorporated by propagating wave fields (Garrison et al. 1983, Gradinger \& Ikävalko 1998 and references therein). Bacterial enrichment in newly forming ice can occur (see Gradinger \& Ikävalko 1998); there are no data for viruses. Congelation ice grows under quiescent conditions or after an ice sheet forms, so increases in cell or viral abundance would presumably be due to growth or release, respectively, in situ. We found no difference in viral abundance in ice core sections consisting of frazil, congelation, or mixed frazil and congelation ice. Additionally, in our data set viral abundance did not differ among surface, internal, and bottom habitats. These results and the variability among samples (Fig. 2) illustrate the heterogeneity of habitats within sea ice. This differs from, for example, the water column where organisms and viruses typically show an abundance pattern related to depth.

Because viruses require host organisms for production and because extracellular viruses are lost over time by a variety of processes (see Wommack \& Colwell 2000), the data indicate that viral infections occurred from 66 to $78^{\circ} \mathrm{S}$ in late autumn. Infected cells were therefore present going into winter. Although we are not absolutely certain that these viruses infect algae and protozoans rather than bacteria, their large size and morphologies are consistent with characteristics of algal and protozoan viruses (see reviews by van Etten et al. 1991, Reisser 1993, Proctor 1997), and they are larger than marine viruses known to infect bacteria (e.g. Weinbauer \& Peduzzi 1994). As noted in the methods section, we did not count viruses $<110 \mathrm{~nm}$ that infect algae and protozoans; therefore we did not sample total eukaryotic viruses. Abundances of the large viruses were positively correlated with chl $a$, a bulk measure of algal biomass, and with phaeophytin, an indicator of degradation of chlorophyll by grazing or senescence. Because viruses must attach to host cells, viral abundance should be highest where host cell abundance is highest, and the highest abundance $\left(>9 \times 10^{5} \mathrm{ml}^{-1}\right.$ brine) of larger viruses did occur in core sections that were visibly green at Stns 146, 159 and 160. Pigment measurements and cell counts were made at Stns 159 and 160. Chl $a$ at the depths of highest viral abundances ranged from 16 to $73 \mu \mathrm{g} \mathrm{l}^{-1}$, and phaeophytin ranged from 0.5 to $27 \mu \mathrm{g} \mathrm{l}^{-1}$. The most abundant ( $>10^{5}$ cells $\mathrm{ml}^{-1}$ melted sample) autotrophs included non-motile Phaeocystis spp. cells, chrysophyte cysts, Mantoniella spp., Gymnodinium spp., and several species of diatoms. Several different species of diatoms were present in abundance $>10^{4} \mathrm{ml}^{-1}$ melted sample. The most abundant $\left(>10^{5} \mathrm{ml}^{-1}\right.$ melted sample) heterotrophs included choanoflagellates, unidentified flagellates, euglenoids, Cryothecomonas spp. and Telonema antarctica. Therefore there was a diversity of eukaryotes present in high abundance that were possible sources of the large viruses.

Viruses are only visible in a host during a short part of the lytic cycle (see discussion in Binder 1999), and in natural samples only a small percentage of cells may be undergoing lysis. During plankton blooms, when viral infections are known to occur, the percentage of visibly infected cells varies from $<1$ to 50 and is commonly <10 (e.g. Bratbak et al. 1993, Nagasaki et al. 1994, Brussaard et al. 1996). We looked at sections through more than 9000 diatom cells, and given the high abundance (from cell counts), we probably examined an adequate number of several species and saw no viruses in any of them. Interestingly, there is only one report (Proctor \& Fuhrman 1991) of viruses infect- 
ing diatoms; the putative viruses causing lysis of the pennate diatom (Navicula sp.) culture of Suttle et al. $(1990,1991)$ were subsequently determined to be $0.2 \mu \mathrm{m}$ filterable, species-specific pathogenic bacteria (Chan et al. 1997, Suttle 2000). Diatoms and dinoflagellates may be less susceptible to viral infections than other algae because of their cell covering and exudate production (Zingone 1995). Diatoms would seem to have been an unlikely source of the larger viruses in our samples.

The lack of infected heterotrophs and non-diatom algal cells may have been because we simply did not look at enough cells of the numerically dominant species or because infected cells were not present. In most samples we probably only looked at a few specimens of any species. For Stns 159 and 160 (Table 3) where we looked at a large number of heterotrophs, there was also a high diversity of heterotrophs. It is also possible that our preparation methods caused infected cells to lyse (and thus not be observed) because processing ice cores did involve dilution along with osmolarity changes. However, we used the same methods during a summer study and observed numerous infected cells of 3 (albeit different) flagellate taxa (Gowing 1999). The sizes of the viruses in the late autumn infected heterotrophs were generally larger than most of the free viruses (Fig. 4). This suggests that there were other infected taxa in the ice.

Viruses were being consumed in late autumn, as evident by their presence in fecal pellets from ice samples and within food vacuoles of phaeodarian radiolarians from water directly below the ice at several stations. Based on size and contents, most of the small fecal pellets observed with viruses were probably produced by protozoans, although a few contained pulverized silica, suggesting a metazoan producer. Some of the viruses may have been digested, as only their outer boundaries remained, but others looked ultrastructurally intact. In most cases, the intact larger viruses appeared to have been ingested as individuals or as part of a particle rather than as infected cells because only 1 or a few viruses were observed in a section. One pellet contained a cluster of $>24$ uniform (ca. $186 \mathrm{~nm}$ diameter) empty capsids. That is consistent with digestion of an infected cell; however, no remnants of the cell were recognizable. Three pellets contained clusters of small (50 to $80 \mathrm{~nm}$ ) viruses, consistent with digestion of infected bacteria. We observed sections through more than 804 microheterotrophs of a variety of taxa from the ice cores and brine hole samples but saw no viruses in food vacuoles. Viruses thus do not appear to be an important food source for ice community microheterotrophs at the time of our study. Whether this is due to avoidance of viruses or to their low abundance is not known.
Viruses in sea ice have only been investigated in one Arctic study (Maranger et al. 1994a). Abundance of viruses (<50 nm to $120 \mathrm{~nm}$ capsid diameter) in the bottom of the ice ranged from $9.0 \times 10^{6}$ to $1.5 \times 10^{8} \mathrm{ml}^{-1}$ melted sample during a month of the spring algal bloom (Maranger et al. 1994a). Total (all sizes) viruses in the late autumn Ross Sea core sections were within this range (Table 3). Maximum viral abundance in Southern Ocean water column samples generally ranged from $10^{5}$ to $10^{7} \mathrm{ml}^{-1}$ (Smith et al. 1992, Bird et al. 1993, Maranger et al. 1994b, Marchant et al. 2000). Maxima in Antarctic lake samples ranged from ca. $10^{6}$ to $10^{8} \mathrm{ml}^{-1}$ (Kepner et al. 1997, 1998, Wilson et al. 2000). In contrast, abundance in the 17 core sections from the Ross Sea (Table 3) was generally higher, ranging from $10^{8}$ to $10^{9} \mathrm{ml}^{-1}$ brine. Thus Antarctic sea ice is a habitat of high viral abundance, and the total viral community is likely to play a role in ice community dynamics.

In summary, large viruses are present in a variety of Antarctic sea ice microhabitats in late autumn and from the ice edge to the continent. Size data indicate that several eukaryotic taxa are probably infected, although we saw direct evidence of infection for only an unidentified heterotroph. Diatoms were unlikely to have been the source of the large viruses. Abundances of large viruses were positively correlated with chl $a_{\text {, }}$ but did not show an obvious relationship with microhabitat or ice structure. Abundances of large viruses reached a maximum of $2.5 \times 10^{6} \mathrm{ml}^{-1}$ brine, whereas total (all sizes) viruses from a subset of samples ranged from $10^{8}$ to $10^{9} \mathrm{ml}^{-1}$ brine. These abundances suggest roles for viruses in sea ice communities comparable to those in other ecosystems, but not as a food source for ice heterotrophs.

Acknowledgements. We thank the captain and crew of the RV 'Nathaniel B. Palmer' and J. Barnes and the Antarctic Support Associates team for making the cruise a success. We thank C. Venn for help with sample collection and processing on the cruise, J.-L. Tison for help with ice coring, N. Wilson and T. Haskell for coring brine holes, Y. Okolodkov for taking the plankton tows and water samples, R. Zalpuri and P. Sicurello of Univ. California Berkeley for thin sectioning, L. C. van De Werfhorst for laboratory help, H. Thomsen, O. Moestrup, N. Daugbjerg and H. Marchant for taxonomic consultations, D. Bird, J. Fuhrman, G. Steward and C. Suttle for advice on filter preparations, R. T. Hinegardner for discussions and for reviewing the manuscript, 2 anonymous reviewers for constructive suggestions, J. W. Tamkun for facilitating our use of the ultracentrifuge, and J. M. Krupp for help with electron microscopy. This research was supported by National Science Foundation grants OPP9725136 to M.M.G., OPP 9614201 to D.L.G. and OPP9614844 to M.O.J. and S. Li. Interpretations and conclusions are those of D. L. Garrison and do not imply the endorsement of the National Science Foundation. 


\section{LITERATURE CITED}

Ackley SF, Sullivan CW (1994) Physical controls on the development and characteristics of Antarctic sea ice biological communities-a review and synthesis. Deep-Sea Res Part I 41:1583-1604

Binder B (1999) Reconsidering the relationship between virally induced bacterial mortality and frequency of infected cells. Aquat Microb Ecol 18:207-215

Bird DF, Maranger R, Karl DM (1993) Palmer LTER: Aquatic virus abundances near the Antarctic Peninsula. Antarct J US 28:234-235

Bratbak G, Egge J, Heldal M (1993) Viral mortality of the marine alga Emiliania huxleyi (Haptophyceae) and termination of algal blooms. Mar Ecol Prog Ser 93:39-48

Brussaard CPD, Kempers RS, Kop AJ, Riegman R, Heldal M (1996) Virus-like particles in a summer bloom of Emiliania huxleyi in the North Sea. Aquat Microb Ecol 10:105-113

Cachon J, Cachon, M (1985) III. Class Phaeodarea Haeckel, Emend Haecker, Reschetnjak. In: Lee JJ, Hutner SH, Bovee EC (eds) Illustrated guide to the Protozoa. Society of Protozoologists, Lawrence, KS, p 295-302

Chan AM, Kacsmarska I, Suttle CA (1997) Isolation and characterization of a species specific bacterial pathogen which lyses the marine diatom Navicula puchipora. Abstract, American Society of Limnology and Oceanography Aquatic Sciences Meeting, February 1997, Santa Fe, NM

Cochlan WP, Wilkner J, Steward GF, Smith DC, Azam F (1993) Spatial distribution of viruses, bacteria and chlorophyll $a$ in neritic, oceanic and estuarine environments. Mar Ecol Prog Ser 92:77-87

Cox GFN, Weeks WF (1983) Equations for determining the gas and brine volumes in sea-ice samples. J Glaciol 29:306-316

Fritsen C, Lytle VI, Ackley SF, Sullivan CW (1994) Autumn bloom of Antarctic pack-ice algae. Science 266:782-784

Fuhrman JA (1999) Marine viruses and their biogeochemical and ecological effects. Nature 399:541-548

Garrison DL (1991) Antarctic sea ice biota. Am Zool 31:17-33

Garrison DL, Buck KR (1986) Organism losses during ice melting: A serious bias in sea ice community studies. Polar Biol 6:363-365

Garrison DL, Ackley SF, Buck KR (1983) A physical mechanism for establishing algal populations in frazil ice. Nature 306:363-365

Garrison DL, Gibson A, Neenan D, Coale SL, Fritsen C, Jeffries MO, Ikävalko J, Okolodkov YB (1999) Early stages of ice community development observed in a transect across the Ross Sea, May-June 1998. EOS Trans Am Geophys Union 80:OS110

González JM, Suttle CA (1993) Grazing by marine nanoflagellates on viruses and virus-sized particles: ingestion and digestion. Mar Ecol Prog Ser 94:1-10

Gowing MM (1989) Abundance and feeding ecology of Antarctic phaeodarian radiolarians. Mar Biol 103:107-118

Gowing MM (1993) Large virus-like particles from vacuoles of phaeodarian radiolarians and from other marine samples. Mar Ecol Prog Ser 101:33-43

Gowing MM (1999) Viruses of algae and protozoans in austral summer Ross Sea pack ice communities. EOS Trans Am Geophys Union 80:OS38

Gradinger R, Ikävalko J (1998) Organism incorporation into newly forming Arctic sea ice in the Greenland Sea. J Plankton Res 20:871-886

Gradinger R, Weissenberger J, Beyer K (1993) Sea-ice biological investigations. In: Spindler M, Dieckmann G, Thomas D (eds) The expedition ANTARKTIS X/3 of RV 'Polarstern' in 1992. Berl Polarforsch 121:59-67
Horner RA (1985) Sea ice biota. CRC Press, Boca Raton, FL

Hoshiai T (1985) Proliferation of ice-algae in Antarctic seaice. In: Siegfried WR, Condy PR, Laws RM (eds) Antarctic nutrient cycles and food webs. Springer-Verlag, Berlin, p 89-92

Jeffries MO, Adolphs U (1997) Early winter ice and snow thickness distribution, ice structure and development of the western Ross Sea pack ice between the ice edge and the Ross Ice Shelf. Antarct Sci 9:188-200

Jeffries MO, Krouse HR, Hurst-Cushing B, Maksym T (2001) Snow ice accretion and snow cover depletion on Antarctic first-year sea ice floes. Ann Glaciol 33:51-60

Karl DM, Christian JR, Dore JE, Letelier RM (1996) Microbiological oceanography in the region west of the Antarctic Peninsula: Microbial dynamics, nitrogen cycle and carbon flux. In: Ross R, Hoffman E, Quetin L (eds) Foundations for ecosystem research west of the Antarctic Peninsula. AGU Antarctic Res Ser 70:303-332

Kepner RL, Wharton RA Jr, Galchenko V (1997) The abundance of planktonic virus-like particles in Antarctic lakes. In: Lyons WB, Howard-William H, Hawes I (eds) Ecosystem processes in Antarctic ice-free landscapes. AA Balkema, Rotterdam, p 241-250

Kepner RL, Wharton RA, Suttle CA (1998) Viruses in Antarctic lakes. Limnol Oceanogr 43:1754-1761

Lawrence JE, Chan AM, Suttle CA (2001) A novel virus (HaNIV) causes lysis of the toxic bloom-forming alga Heterosigma akashiwo (Raphidophyceae). J Phycol 37:216-222

Lund JWG, Kipling C, LeCren ED (1958) The inverted microscope method of estimating algal numbers and the statistical basis of estimations by counting. Hydrobiologia 11:143-170

Maranger R, Bird DF, Juniper SK (1994a) Viral and bacterial dynamics in Arctic sea ice during the spring algal bloom near Resolute, N.W.T., Canada. Mar Ecol Prog Ser 111:121-127

Maranger R, Bird DF, Karl DM (1994b) Palmer LTER: Spatial distribution of viruses in the Palmer LTER region. Antarct J US 29:209-211

Marchant H, Davidson A, Wright S, Glazebrook J (2000) The distribution and abundance of viruses in the Southern Ocean during spring. Antarct Sci 12:414-417

Mazia D, Schatten G, Sale W (1975) Adhesion of cells to surfaces coated with polylysine. J Cell Biol 66:198-200

Nagasaki K, Ando M, Itakura S, Imai I, Ishida Y (1994) Viral morphology in the final stage of Heterosigma akashiwo (Raphidiphyceae) red tide. J Plankton Res 16:1595-1599

Noble RT, Fuhrman JA (1998) Use of SYBR Green I for rapid epifluorescence counts of marine viruses and bacteria. Aquat Microb Ecol 14:113-118

Palmisano AC, Garrison DL (1993) Microorganisms in Antarctic sea ice. In: Freemann IE (ed) Antarctic microbiology. Wiley, New York, p 167-218

Proctor LM (1997) Advances in the study of marine viruses. Microsc Res Tech 37:136-161

Proctor LM, Fuhrman JA (1991) Roles of viral infection in organic particle flux. Mar Ecol Prog Ser 69:133-142

Reisser W (1993) Viruses and virus-like particles of freshwater and marine eukaryotic algae-a review. Arch Protistenkd 143:257-265

Reynolds ES (1963) The use of lead citrate at high pH as an electron-opaque stain in electron microscopy. J Cell Biol 17:208-212

Smith DC, Steward GF, Azam F, Hollibaugh JT (1992) Viruses and bacteria abundances in the Drake Passage during January and August 1991. Antarct J US 27:125-127 
Spurr AR (1969) A low-viscosity epoxy resin for embedding medium for electron microscopy. J Ultrastr Res 26:31-49

Steward GF, Smith DC, Azam F (1996) Abundance and production of bacteria and viruses in the Bering and Chukchi Seas. Mar Ecol Prog Ser 131:287-300

Suttle CA (1993) Enumeration and isolation of viruses. In: Kemp PF, Sherr BF, Sherr EB, Cole JJ (eds) Aquatic microbial ecology. Lewis Publishers, Boca Raton, FL, p 121-133

Suttle CA (2000) The ecological, evolutionary and geochemical consequences of viral infection of cyanobacteria and eukaryotic algae. In: Hurst CJ (ed) Viral ecology. Academic Press, London, p 248-286

Suttle CA, Chan AM, Cottrell MT (1990) Infection of phytoplankton by viruses and reduction of primary productivity. Nature 347:467-469

Suttle CA, Chan AM, Cottrell MT (1991) Use of ultrafiltration to isolate viruses from seawater which are pathogens of marine plankton. Appl Environ Microbiol 57:721-726

van Etten JL, Lane LC, Meints RH (1991) Viruses and virus like particles of eukaryotic algae. Microbiol Rev 55:586-620

Editorial responsibility: Jed Fuhrman (Contributing Editor), Los Angeles, California, USA
Weinbauer MG, Peduzzi P (1994) Frequency, size and distribution of bacteriophages in different marine bacterial morphotypes. Mar Ecol Prog Ser 108:11-20

Wilhelm SW, Weinbauer MG, Suttle CA, Jeffrey WH (1998) The role of sunlight in the removal and repair of viruses in the sea. Limnol Oceanogr 43:586-592

Wells ML, Goldberg ED (1992) Marine submicron particles. Mar Chem 40: 5-18

Wilson WH, Lane D, Pearce DA, Ellis-Evans, JC (2000) Transmission electron microscope analysis of virus-like particles in the freshwater lakes of Signy Island, Antarctica. Polar Biol 23:657-660

Wommack KE, Colwell RR (2000) Virioplankton: Viruses in aquatic ecosystems. Microbiol Mol Biol Rev 64:69-114

Xenopoulos MA, Bird DF (1997) Virus à la sauce Yo-Pro: Microwave-enhanced staining for counting viruses by epifluorescence microscopy. Limnol Oceanogr 42: 1648-1650

Zingone A (1995) The role of viruses in the dynamics of phytoplankton blooms. G Bot Ital 129: 415-423

Submitted: October 4, 2001; Accepted: March 26, 2002

Proofs received from author(s): September 9, 2002 